Fictions of State 
Also by Patrick Brantlinger-

Bread and Circuses:

Theories of Mass Culture as Social Decay

Rule of Darkness:

British Literature and Imperialism, I830-1914 


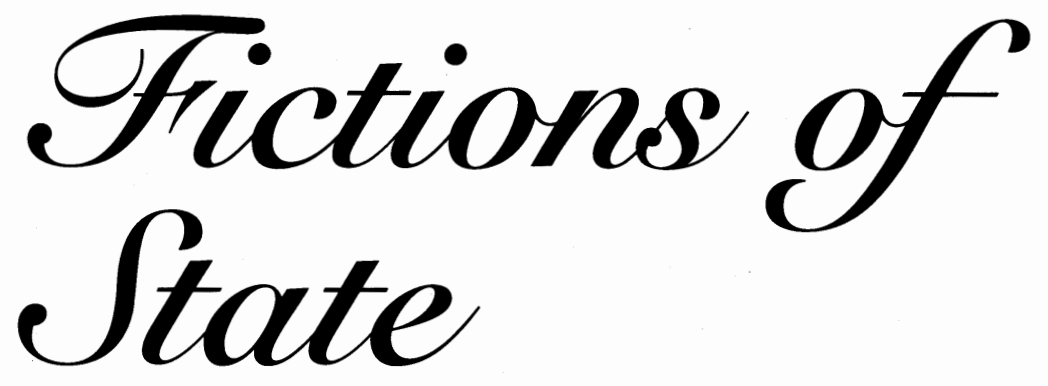

Culture and Credit in Britain, 1694-1994

\section{Patrick OBrantlinger}




\section{Copyright $\mathbb{C} 1996$ by Cornell University}

All rights reserved. Except for brief quotations in a review, this book, or parts thereof, must not be reproduced in any form without permission in writing from the publisher. For information, address Cornell University Press, Sage House, $5^{12}$ East State Street, Ithaca, New York $14^{8} 5^{0}$.

First published 1996 by Cornell University Press.

Printed in the United States of America

Library of Congress Cataloging-in-Publication Data

Brantlinger, Patrick, 1941-

Fictions of state : culture and credit in Britain, 1694-1994/ Patrick Brantlinger.

p. $\mathrm{cm}$.

Includes bibliographical references (p. ) and index.

ISBN o-8014-3190-5 (alk. paper). — ISBN o-8014-8287-9 (alk. paper)

1. English fiction-History and criticism. 2. Economics in literature. 3. Literature and state-Great Britain. 4. Great Britain-Economic conditions. 5. Popular culture-Great Britain. 6. Credit-Great Britain. 7. Debt in literature. I. Title. PR83o.E $37 B_{73} \quad 1996$

823.009' 355 -dc2o

(2) The paper in this book meets the minimum requirements of the American National Standard for Information SciencesPermanence of Paper for Printed Library Materials, ANSI Z39-48-1984. 
To Ellen 
